\title{
創造的合意形成ツールとしての DEVELOPMENT OF "DESIGN 「デザイン・ランゲージ」の開発 LANGUAGE" FOR CREATIVE CONSENSUS
}

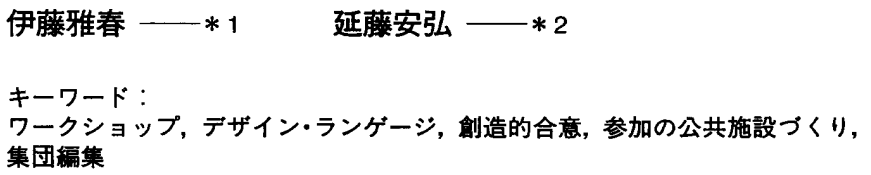

\section{Keywords :}

Workshop, Design language, Creative consensus, Planning public facilities through community participation, Editting together

\section{Masaharu ITO $-* 1 \quad$ Yasuhiro ENDO $-* 2$}

This paper shows the effects of a method called "Design Language" developed for planning public facilities through community participation. In this study, we pay attention to the idea of editting together. The process of editting "Design Language" by participants is an original method.

The three effects are following;

- "Design Language" is an effective method as a communication tool for various participants.

- "Design Language" is an effective method as a creative tool by which participants imagine a space.

- "Design Language" is an effective method as a tool for creative consensus among participants.

\section{1 .デザイン・ランゲージの理論的背景}

本研究の目的は、参加の施設づくりワークショップ（以下、 WS とする) の手法の一つとして開発した「デザイン・ランゲ ージ」が設計者と参加者をつなぐ有効なッールであることを検 証することにある。

デザイン・ラングージのアイデアは、パタン・ランゲージ1 にそのヒントを得ている。パタン・ランゲージでは空間と行為 をセットにした 253 のパタンが提示され、ユーザーが空間の 質を理解する手引き書になっている。C・アレグザンダーは設 計プロセスの中でユーザーからヒアリングした空間イメージを 文章化する作業を行っているが、この文章化の作業はパタン・ ラングージの中では説明されていない。

開発にあたっては、W S 参加者の合意形成の意味を「わかり 合う」プロセスとして理解し、人間によって「わかる」という 意識を持つためには、そこに参加することが不可欠であるとす る佐伯胖氏の理論 ${ }^{2}$ を参考にしている。空間イメージを言葉に よって物語化するデザイン・ラングージ ${ }^{33}$ 創造的合意形成の

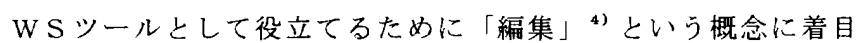
し、実践の場で利用できる編集プロセスの手法化を進めた点に この研究のオリジナリティがある。ここでいう編集とは、設計 者上参加者が文章化した空間イメージを協同で修正していくプ ロセスのことである。

\section{2.デザイン・ランゲージの開発経緯}

まず、「デザイン・ランゲージ」とは何かを定義しておこう。
住民参加の施設づくりを目的としたW Sの場において、参加者 から引き出された多くの意見をどのように設計に生かしていく ことができるか、という問題は、参加の施設づくりに取り組む 設計者が必ず頭を悩ませる課題である。デザイン・ラングージ は、あたかもその空間が存在し、その施設を訪れ、その場の出 来事を語るようにW Sで語られた多くの言葉をつないで、施設 の空間イメージを文章化し、物語のように表現する手法である。

デザイン・ランゲージの開発が、とりわけ住民参加が求めら れる公共施設の設計プロセスにおいて、必要でありかつ有効で あると考えたのは、次の上うな理由による。

(1)図面のわからない子どもや高齢者でも空間イメージを理解し、 提案できる言葉を手段とすることで、空間の専門家と利用者の コミュニケーションの可能性を広げる。

(2)空間とそこで行われる行為を絶えずセットで考えることを可 能にする。

(3)編集という作業を介してより多くの人の参加を可能にし、お 互いに「わかり合う」関倸をつくり出すことによって空間イメ ージの合意をつくることができる。

(4)空間を一度、言葉に置き換え情報伝達することで、情報を伝 え合う双方に創造的な余地老つくり出す。5

筆者が現在までに、実践の場で試みてきたデザイン・ランゲ ージ開発の経緯を表 1 に示す。今回報告する事例(6)は、デザイ ン・ランゲージの編集作業としてアンケート形式に加えて集団 編集方式を試み、合意形成を目的としたW Sの手法として一応 の成果を上げた事例である。

*1 侑)大久手計画工房 所長 


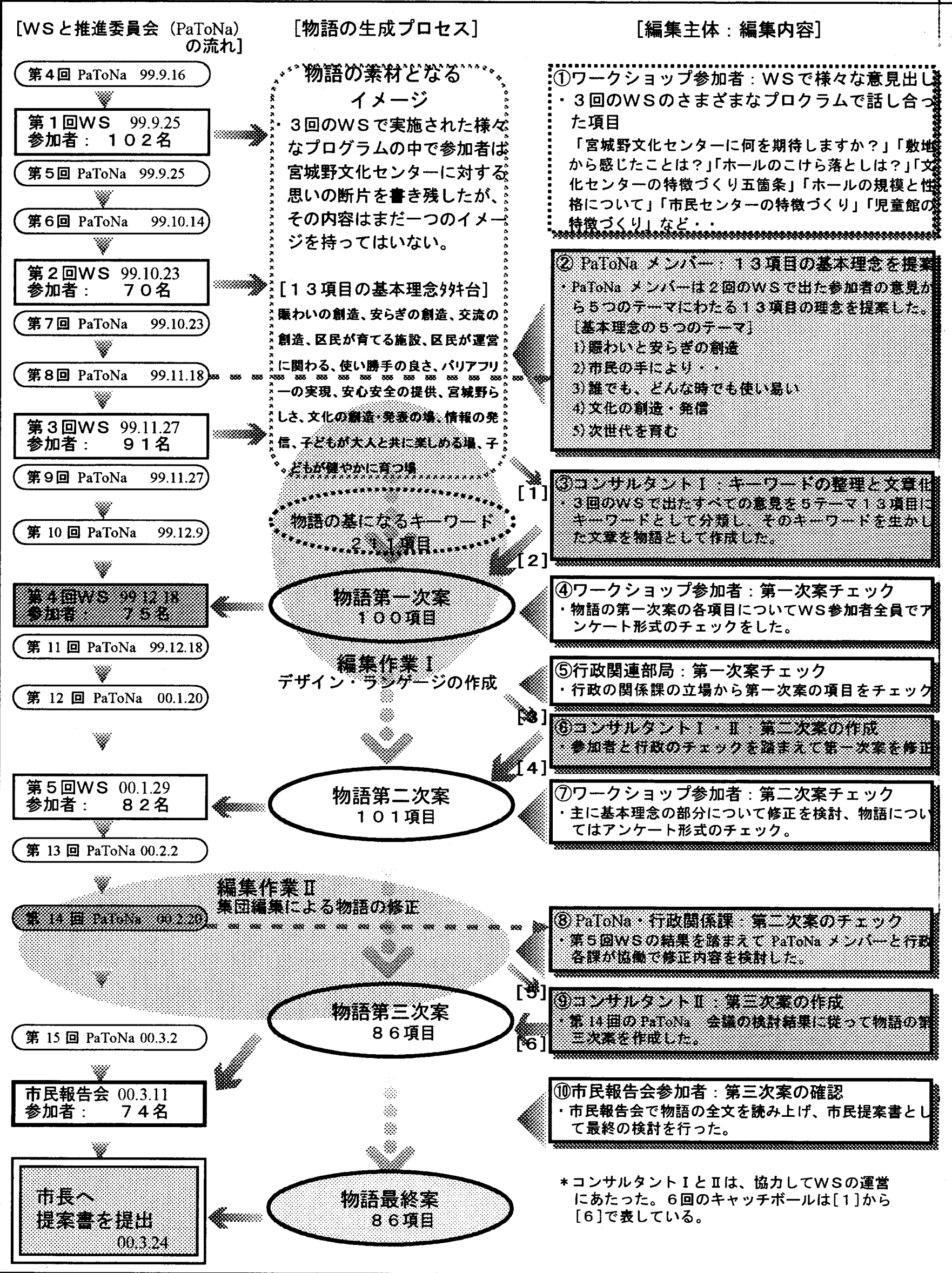

図 2 「宮城野文化センター物語」の編集プロセス 
表 1 デザイン・ランゲージの開発経緯

\begin{tabular}{|c|c|}
\hline & 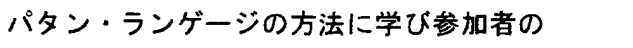 \\
\hline 19 & 空間イメージをヒアリングして \\
\hline 事化 & デサインゲームの結果を文章化し、コアメンバー \\
\hline 199 & が編集したデザイン \\
\hline 事例 & WS参加者の声を編集しデザイン・ランゲージを \\
\hline 1993年 & 作成、参加者合意のうえ基本言 \\
\hline 事例(4) & 参加者全員がデサイン・ランゲー \\
\hline 1996年 & 参加できるアンケートによる \\
\hline 事例(5) & アンケートによる編集方式を方法 \\
\hline 1998年 & 者の合意に基づく「物語」方式の \\
\hline 事例(6) & 編集プロセスに参加者による \\
\hline 1999年 & えて、コアメンバーの集団編集作業の試みを実施 \\
\hline
\end{tabular}

\section{3.デザイン・ランゲージの作成プロセス}

まず、今回報告する仙台市の取り組みの概要を明らかにしておく 必要がある。この事業は、宮城野区文化センターを区のシンボルと して位置づけ、行政と市民が協働で建設計画を策定することを目的 として平成 11 年度に実施された。(図 2 ) 事業の特徽としては、 市民の声をまとめる作業を市民自身が主体的に行うために公募によ る事務局を組織したこと、参加の手法としてW S を実施し、審議会 や委員会を設置せず、あくまでもWSの場において計画案をまとめ ることを原則としたこと、の二点である。以下に今回のW S の枠組 み上、デザイン・ラングージレしての「宮城野文化センター物語」 の関係を図 1 に整理しておく。
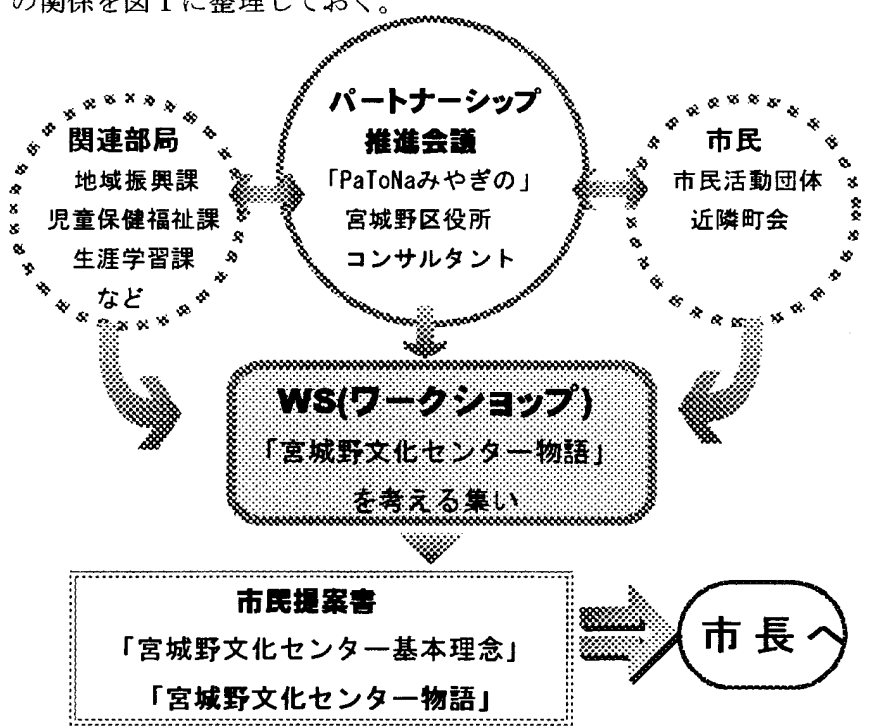

图1 W Sの枠組み

$\lceil\mathrm{PaToNa}$ みやぎの」とは、仙台市が市民参加に上って宮城野区 文化センターの基本構想を策定するため、とりまとめ役として公募 した市民 20 名による事務局。正式名称は、宮城野区文化センター 等基本構想策定パートナーシップ推進会議。

「市民提案書」とは、15回に及ぶ推進会議と 5 回のWS を経て 「PaToNa みやぎの」によってま上められた基本構想である。 その内容は「宮城野文化センター基本理念（13 項目〉と「宮城野 文化センター物語（86 項目)」によって構成されている。

「宮城野文化センター物語」（以下物語とする）上は、今回参加 者が合意したハードとソフトを含む施設イメージをデザイン・ラン ゲージの手法によって文章化したものである。
た上えば、物語の「1．にぎわい、ふれあい、やすらぎ」注7の 中の「1.2.ふ九れあい場」の1項目について、その生成プロセスを 見てみ上う。(表 2)

表 2 物語の 1 項目を通して見たランゲージの編集プロセス (1)第 1、2、3 回WSの記録の中から拾い出されたキーワード

・出会い、触れ合い、語り合い.広場のような文化センター ・家の中にこもっている人、誰かのために自分を役立てたい上思 っている人、仲間を求めている人・だれでも（高㱓者と児童た ち）が気軽に利用できるような場を一室作って欲しい・文化セ ンターらしい軽食も取机る喫茶店・1階ロビーにコミュニケー ションのスペースを・交流の場や休嚊所のある広いロビー・高 跉者の集まる場所が欲しい・手続きをしないで気軽に使えるス ペース・娛楽室は、自由に高齢者なよ゙が集えるようなオープン な場になったらよいのでは・いつでも自由に遊びに来られる場 所であってほしい・市民活動室はボランティアの連絡の場・い ろいろな市民グループの集える場所に・囲碁や将棋はロビーの 見えるところで行ら方が交流が生まれるし、利用しや寸い

(2)「編集作業I」によって文章化された物語

・ゆったりした一階ロビーには情報センターの他に宮城野区のボ ランティア団体やN P O の活動抓点になっている市民活動室、手 続きなしで使える交流スベース、囲基や将棋も楽しめる少人数の 談話コーナー、展示コーナー、区民広場に面した障害者グループ が運営する喫茶店などがつながっています。

(3)第 4 回WSで行ったアンケートの結果と、寄せられた意見

（おおむね賛成：81 賛成しかねる:6 よくわからない:11） ・宮城野区に限定しなくてもよいと思う・趣味のサークルも市 民活動室的なところを使えれば・高齢者グループだっていいじ やない！・部屋は有料にす心゙き・『囲碁や将棋も楽しめる少人 数の談話コーナー』を削る・障害者グループが運営するは絞り 込みすぎな感じがする・ここに宮城野区社会福祉協議会の事務 所があるとよいかな? ・手続きなしで使える交流スペースがあ ることは嬉しいことです，宮城野区社会福祉協議会事務所を是 非入れて欲しい。（官民一体の区役所との関連からも!!）そして ボランティア各種の要であるために・話し相手になってくれる 上うなボランティアで雾囲気づくりができると尚よい.非常に よいが反面不安も・市民活動がどれだけあるのか・いろんな部 屋が一階に集中しがちです。基本計画では階の構成について検討 する必要がある・現実的でない

(4)物語第二次案でコンサルタントが作成した修正案

· 1 階には中央児童館、区情報センター、事務室が独立してある ほか、交流の中心となるらったりとしたロビーがあり、ボランテ イア団体やN P Oの活動执点になっている市民活動室、手続きな しで使える交流スペース、少人数の談話コーナ一、展示コーナー が吹き抜け空間などをうまく利用しながらつながっています。

(5)「編集作業II」を経た「PaToNaみやぎの」と行政の合意文書 1.2.3.1 1 階には、中央児童館と区情報センター、事務室が独立し てあるほか、交流の中心となるゆったりとしたロビーがあります また、ボランティア団体やN P Oの活動拠点になっている市民活 動室、手統きなしで使える交流スペース、少人数の談話コーナー 展示コーナーが吹き抜け空間などによってつながっています。 
4.デザイン・ランゲージによる創造的合意形成

デザイン・ランゲージの手法による合意形成の効果を参加者の意 識変容という点から評価するために、各回のWSの最後に参加者に 記入してもらった感想カードの内容を分析する。

表 3 感想カードに表れた参加者の意識の変化

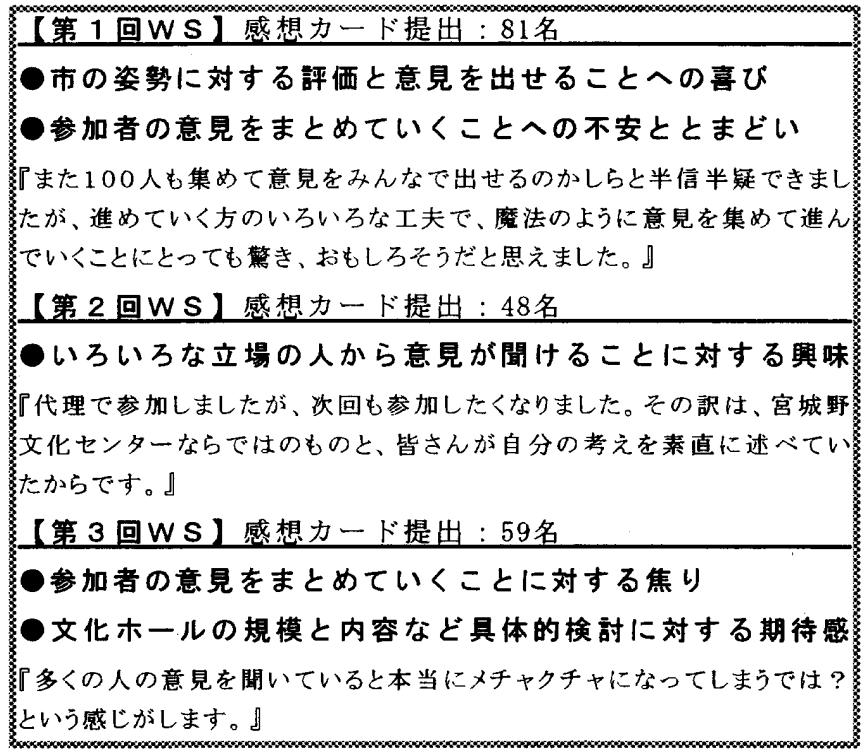

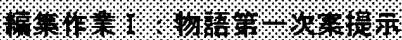

【第 4回WS】感想カード提出：51名

○少しづつまとまってきたことに対する安心感

ままた話し足りないことへの不満とまとめ方に対する不安 阶まだつかみどころのないような、イライラが積もっておりましたが、とて もよい物語を作って下さったことに感心いたしました。』

【第 5 回WS \感想カード提出: 49 名

○PaToNa みやきの」に対する高い評洒と信頼感の表明 市民と行政のパートナーシップが重要であることへの 気づき

○『基本理念』と『物語』の内容に対する理解と今後へ の期待

運営方法については「市民と行政との積整的なパートナーシップ」に より決めていくようにすることが、今後の市民社会のために必要と思い ます。PaToNaのみなさん頋張って下さい。』

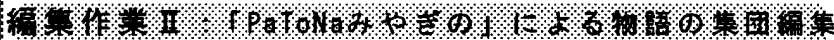
【市民報告会】感想力しト提出: 38 名

市民提案書がまとまったことへの達成感と满足感

○『物語』を通したイメージの共有と共感の広がり

○さらなる参加への意欲の表明と今後への期待感

「心地よい陽さしの中、電車が廃止された線路を浮き立つ気持ちで歩 きました。宫城野原を過ぎ、いよいよ陸前原，町の駅舎と区役所が現 れ、そして霜枯れた草の空地が私たちを迎えてくれました。あっ、この 空地に「私たちの思いを織り上げた」文化センターが表れるのも遠い未 来ではないと思った時、ワークショップに参加し、少しでも関わりを持て たことに誇りさえ感じました。』

『今日報告にあった「基本理念」及び「物語」は、ワークショップ参加者 とPaToNaの皆さんの熱い思いがいっぱい詰まっている貴重な宝物 です。』

感想カードの内容の中から特に「合意形成」に関係の哚い記述を 選び出し、その傾向を各回毎にまとめた。さらに、代表的な意見の 変化を見てみると次のようなことが言える。

(1)[編集作業 I ]によって作成した物語を提示した第 4 回W S 節目 として参加者の意識が変化していることが感想カードの記述から読
み上れる。(表 3)

(2) [編集作業 II ]を挟んだ第 5 回W S と市民報告会の感想カードゆ内 容は、基本理念と物語という成果が、参加者の共感を得て合意本形 成しつつあることを伺わせる内容であるが、この背景には、「PaTo Na みやぎの」に対する信頼感上、市民参加に対する積極的な態度中表 明があることを見逃してはならない。

(3)WSの場における物語の修正作業と、「PaToNaみやぎの」の木ン バーと行政職員が合同で行った集団編集作業[編集作業 II ]

$\left\lceil\mathrm{PaToNa}\right.$ みやぎの」の自己組織化 ${ }^{6}$ (自己の作業を通じて新しい 自己自身を産出すること）を促し、参加者の主体的な態度を生み出 しているのである。

\section{5.まとめ}

今回実施した、施設づくり W Sにおける参加者の合意形成ツール としてのデザイン・ラングージ方式は、以下の点で有効であるもと が明らかになった。

(1)多くのW S 参加者の思いを具体的に文章化し表現しているので、 空間イメージが誰にでもわかりやすいものにできた。

(2)アンケート形式の意見フィードバックの手法を加えることで奉加 者全員が物語の編集作業に参加できた。

(3)W Sの場を形成するそれぞれの主体による 10 段階の編集プ中セ ス（図 2)を積み重ねることによって、きめの細かい合意形成才口 セスを実現できた。

(4)W S の場と事務局の 6 回に及ぶキャッチボールを経て、デザイン ・ランゲージによる物語を 3 次案まで作成したことにより、効果的 な創造的合意形成のプロセスを作り上げることができた。

(5)「PaToNa みやぎの」というコアメンバーによる集団編集作業の 実施は、市民の上り積極的な参加意識を引き出し、コアメンバーの 自己組織化を促すことになった。

\section{参考文献}

1) Christopher Alexander et al. : A Pattern Language, Oxfod University Press 1977 2)佐伯 胖 :「わかる」と言うことの意味 岩波書店 1995 年 佐伯 胖:「学ぶ」と言うことの意味 岩波書店 1995 年 3）日本建築学会編：人間一環境系のデザイン 彰国社 1997 年 4) 早稲田大学佐藤滋研究室：まちづくりはダームのように、造形 Nol4 1996.8

5）金子郁容：〈不確奏性と情報〉入門 岩波書店 1990 年 6)エリッヒ・ヤンツ：自己組織化する宇宙工作舎 1986 年 注

注 1 )「世田谷線宮の坂駅界隈づくりコンペ応募案」

注 2 ）「世田谷区都市の公園設計競技応募案」

注 3)「みんなでつくる新飯野診療所」WS

注 4)「玉川田園調布高柃者在宅サービスセンタ 設計ガイド」

注 5 ）「川崎市日吉地区市民館・図書館分館基本構想」WS

注 6）「宮城野文化センタ一物語」W S

注 7 ）「市民提案書」の目次

1.にぎわい、ふれあい、やすやぎ 2. 市民が育てる 3.だれでむ 使いやすい施設 4 . 文化の創造・受発信 5 . つぎの世代を育む [2000年 4 月20日原和受理 2000年 7 月26日採用決定］ 